\title{
CIRCULAR ORBITS AROUND A SPHERICALLY SYMMETRIC RELATIVISTIC CONFIGURATION IN THE PRESENCE OF A PHANTOM SCALAR FIELD
}

We consider exact solutions of the joint system of Einstein equations and phantom scalar field equations with a special massless selfinteraction potential. We studied orbits of the test bodies, which interact only gravitationally, in the space-time corresponding to these solutions. The main attention is paid to the stable circular orbits. We found conditions for existence of disjoint regions of stable circular orbits, which can be separated by regions of unstable orbits or regions of non-existence of circular orbits.

Ключові слова: скалярне поле, орбіти пробних тіл.

Сташко О., студ. Жданов В., д-р физ.-мат. наук, проф. Астрономическая обсерватория

Киевского национального университета имени Тараса Шевченко

\section{КРУГОВЫЕ ОРБИТЫ ВОКРУГ СФЕРИЧЕСКИ-СИММЕТРИЧЕСКОЙ РЕЛЯТИВИСТСКОЙ КОНФИГУРАЦИИ В ПРИСУТСТВИИ ФАНТОМНОГО СКАЛЯРНОГО ПОЛЯ}

\begin{abstract}
Рассмотрены частные точные решения совместной системы уравнений Эйнштейна и уравнений фантомного скалярного поля с ненулевым потенциалом самодействия. Для этих решений проанализировано распределение круговых орбит пробных тел, которые взаимодействуют только гравитационно. Найдены условия, когда существуют несвязные области устойчивых круговых орбит, существование которых может проявить себя через форму релятивистских рентгеновских линий в активных ядрах галактик.
\end{abstract}

Ключевые слова: скаляорное поле, орбиты пробных тел.

Удк 521.182; 523.44

А. Казанцев, канд. фіз.-мат. наук,

Л. Казанцева, канд. фіз.-мат. наук, Астрономічна обсерваторія

Київського національного університету імені Тараса Шевченка

\section{РОЗПОДІЛ ЗА РОЗМІРАМИ АСТЕРОЇДІВ ГОЛОВНОГО ПОЯСУ Й ОКРЕМИХ СІМЕЙСТВ}

Побудовано розподіл за розмірами астероїдів сімейства Еос. При цьому використано базу WISE, що містить альбедо p i розміри D понад 80 тисяч астероїдів. Показник степеня b степеневої залежності розподілу має мінімум при деяких середніх значенням розмірів астероїдів сімейства. Подібна залежність b(D) має місце $i$ для всього поясу астероїдів. Зроблене припущення про можливу схожість механізмів формування всього поясу астероїдів та окремих сімейств.

Ключові слова: астероїди, сімейства астроїдів.

Вступ. Розподіл астероїдів за розмірами визначає приблизну кількість існуючих тіл у різних діапазонах розмірів. Знання такого розподілу вкрай важливе не лише для визначення кількості тіл, але й для з'ясування механізму походження поясу астероїдів і його динамічної еволюції.

Зазвичай, розподіл астероїдів за розмірами описується степеневою залежністю

$$
d N(D)=k D^{-b} d D
$$

де $d N(D)$ - кількість тіл у вузькому діапазоні розмірів $d(D), k$ і $b$ - певні постійні величини. Однак, нині вже встановлено, що в розподілі за розмірами всього поясу астероїдів величини не є постійними у всьому інтервалі значень $D[2,3,6]$. Для тіл максимальних розмірів $(80-150$ км) показник степені $b$ майже постійний і становить близько 2.3. При зменшених розмірах параметр $b$ спочатку досягає мінімуму (менше 1.0) при $D=60-70$ км, а потім починає різко зростати. Уже при $D=10$ км значення $b=3.7$ (рис. 1).

Такий хід величини $b$ наведено в [2]. Сам хід залежності $b(D)$ i, особливо, наявність мінімуму певною мірою може свідчити про механізм утворення поясу астероїдів.

Зважаючи на наведену залежність, можна припустити, що механізм утворення тіл із розмірами більше 80 км відрізняється від механізму утворення тіл менших розмірів. Відмінність механізмів утворення тіл, напевне, може полягати лише в тому, що більш крупні тіла утворилися внаслідок злипання пилинок (планетозималей), а більш дрібні - унаслідок руйнування більш крупних. Однак, тіла розмірами 80-100 км занадто малі для самогравітаційного механізму утворення. Тому пояснення залежності $b(D)$, очевидно, має бути іншим.

Наведений у [2] розподіл було отримано з використанням бази IRAS [5], що мітить альбедо й розміри 2228 астероїдів. У 2011 р. опубліковано каталог WISE [4], де наведено розміри понад 90000 астероїдів. Ці дані можна використати не лише для побудови розподілу за розмірами астероїдів усього поясу, але й для окремих сімейств астероїдів. Нині загальновизнано, що сімейств астероїдів утворюються внаслідок руйнування одного крупного тіла. Отже механізм формування сімейств приблизно відомий. Тому має сенс побудувати залежність $b(D)$ для окремих сімейств.

Розподіл за розмірами окремих груп астероїдів. У базі WISE можна знайти дані про розміри тіл кількох десятків сімейств. Найчисленніше серед них - сімейство Еос. Орбіти астероїдів сімейств зазвичай описуються так званими власними елементами: власні великі півосі $a^{\prime}$, власні ексцентриситети e' і власні нахили і'. Власні елементи орбіт - це звичайні орбітальні елементи, які певним чином усереднені за періоди вікових коливань. Діапазони власних елементів орбіт сімейства Еос: $a^{\prime}=2.94-3.16$ а.о.; $e^{\prime}=0.022-0.144 ; i^{\prime}=8.5^{\circ}-12.8^{\circ}$. Найбільш відомий масив даних власних елементів орбіт всього поясу астероїдів підготовлений за авторства Мілані (А. Мilani) і Кнезевича (Z. Knežević), який доступний на сайті NASA (http//pds.nasa.gov). 


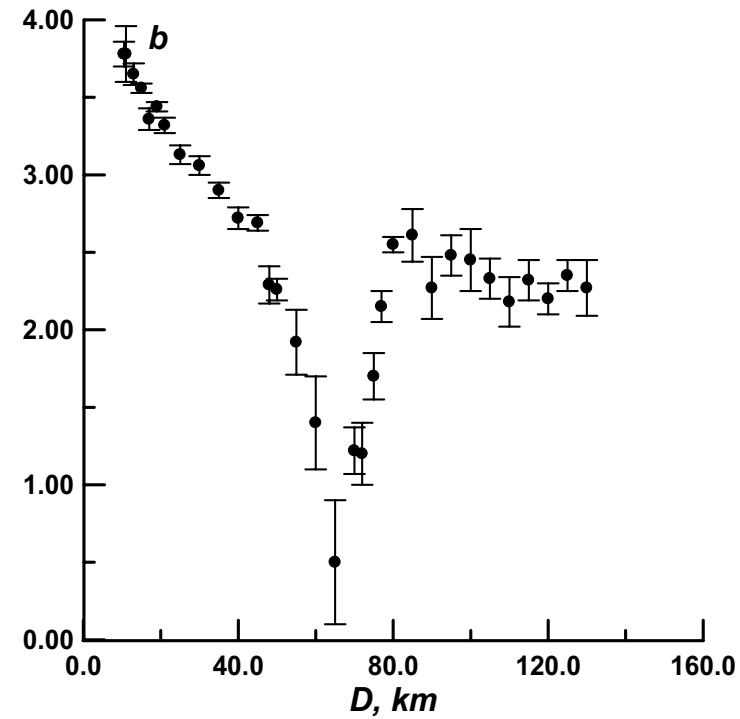

Рис. 1. Залежність параметра $b$ від розмірів астероїдів для ГПА

У базі WISE міститься понад 5500 астероїдів, які можна віднести до сімейства Еос. Така кількість тіл дозволяє побудувати приблизну зміну параметра $b$ за розмірами (рис. 2). Механізм побудови залежності $b(D)$ описано в [2]. Хоча залежність $b(D)$ не дуже чітка, однак, мінімум $b$ при $D \approx 17$ км, очевидно, існує.

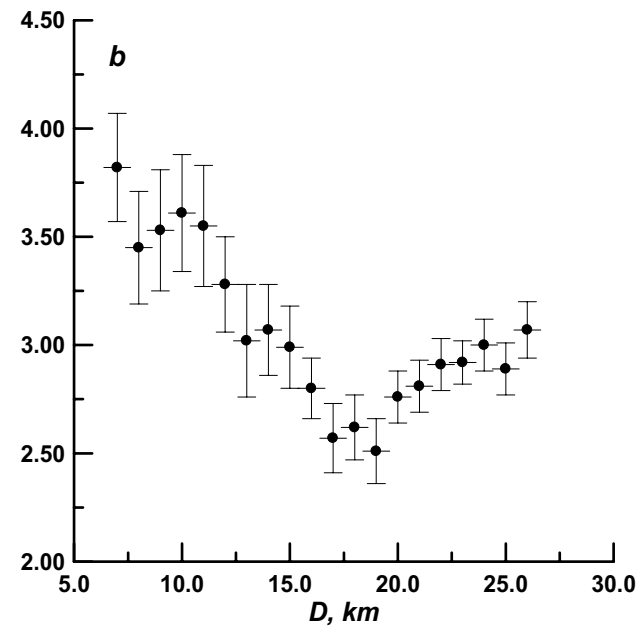

Рис. 2. Залежність $b(D)$ для сімейства Еос

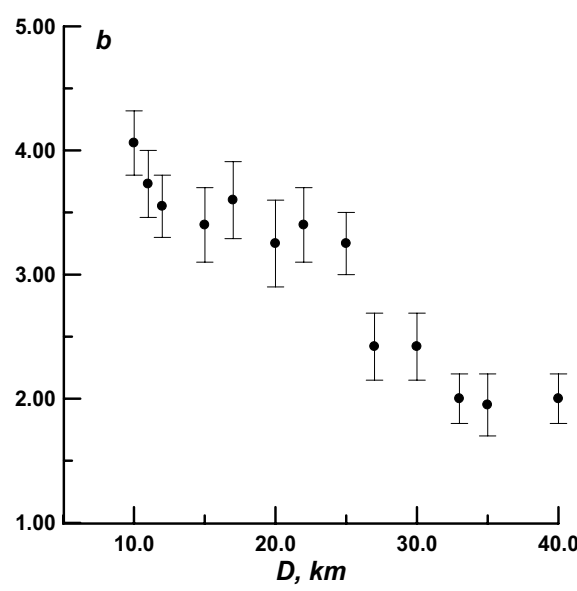

Рис. 3. Розподіл $b(D)$ для астероїдів фону

Отже в розподілі за розмірами уламків руйнування одного крупного тіла, тобто астероїдів утвореного сімейства, $є$ певна ділянка, де параметр $b$ має мінімальне значення. Ця ділянка розташована не при максимальних значеннях розмірів і не при мінімальних.

Хоча залежності $b(D)$ для всього поясу і для сімейства Еос помітно відрізняються, однак якісно, а саме, існуванням мінімуму величини $b$ вони схожі. Наявність мінімуму посередині розподілу $b(D)$ як для всього поясу, так і для окремого сімейства може вказувати на схожість механізмів утворення окремого сімейства та всього поясу астероїдів.

Може виникнути логічне запитанні: а чи не має місце подібна залежність $b(D)$ для будь якої окремої зони поясу астероїдів? Якщо існує, то ця залежність не може вказувати на механізм утворення ні окремого сімейства, ні всього поясу. У такому разі хід залежності $b(D)$ має інше пояснення, яке не пов'язане з походженням тієї чим іншої групи тіл.

Для відповіді на таке запитання за даними бази WISE було побудовано залежність $b(\mathrm{D})$ для астероїдів фону, тобто для тіл, що не належать до жодного сімейства. Така зона в координатах власних елементів була вибрана в середині головного поясу $\left(a^{\prime}=2.60-2.80\right.$ а.о., $\left.e^{\prime}=0.04-0.13, i^{\prime}=2.0^{\circ}-12.0^{\circ}\right)$. Отримана вибірка оминає сусідні сімейства і налічує понад 5000 тіл. Залежність $\mathrm{b}(D)$ для даної вибірки представлено на рис. 3.

Видно, що на відміну від двох попередніх залежностей, на цій залежності мінімум відсутній. Якщо порівняти рис. 1 і рис. 3, то можна побачити, що залежність $b(D)$ для астероїдів фону близька до залежності для всього поясу при розмірах $D<40$ км. Саме так і має бути, оскільки відібрані астероїди фону є частиною вибірки всього поясу астероїдів. Важливо зазначити, що діапазон розмірів астероїдів фону близький до діапазону розмірів тіл сімейства Еос. Однак, мінімум розподілу має місце лише для сімейства.

Певне пояснення можна зробити відносно спостережної селекції. У поясі астероїдів тіла з розмірами більше 10 км відкриті вже всі. Останній астероїд з $H<13^{\mathrm{m}}$, що приблизно відповідає розміру $D>10$ км, відкрито понад 10 років тому. Отже, на залежності на рис. 1 і на рис. 3 відкриття нових тіл не вплинуть. Що стосується рис. 2, то тут залежність представлена до розмірів 5 км. По-перше, у цей час вже відкрито й переважну більшість тіл із розмірами 
від 5 км. По-друге, головна характерна ділянка залежності (з мінімумом) припадає на розміри 15-20 км. Отже, усі три наведені залежності можна вважати вільними від спостережної селекції.

Таким чином, можна припустити, що характер розподілу за розмірами всього поясу астероїдів може бути близьким до характеру розподілу окремого сімейства. Це, у свою чергу, може вказувати на схожість механізмів походження поясу астероїдів та окремих сімейств.

Зрозуміло, що цей висновок є лише попереднім припущенням, яке потребує детальної перевірки на більших масивах розмірів тіл і для більшої кількості сімейств. Якщо залежність $b(D)$ для всього поясу визначена більш-менш точно, що видно з вказаному на рис. 1 розкидом значень $b$, то відповідні залежності для сімейства Еос і для тіл фрону отримані зі значним розкидом цього параметра. Бажано також мати теоретичні результати щодо розподілу за розмірами уламків руйнування одного крупного тіла.

Висновки. Наявність мінімуму залежно $b(D)$ як для всього поясу астероїдів, так і для окремого сімейства може вказувати на схожість механізмів походження поясу астероїдів та окремих сімейств. Для подальшого обґрунтування зробленого припущення потрібне детальніше вивчення цього питання як із використанням ширших масивів даних про розміри астероїдів, так і з теоретичного боку.

Список використаних джерел

1. Казанцев А. М. Некоторые особенности распределения числа астероидов по размерам / А. М. Казанцев // Кинематика и физика небесных тел. 2002. - T. 18. - № 6. - С. 517-524.

2. Казанцев А. М. Уточнення розподілу астероїдів за розмірами та оцінка числа біляземних астероїдів / А. М. Казанцев // Вісн. Київ. нац. у-ту імені Тараса Шевченка. Астрономія - 2008 - № 45. - C. 52-55.

3. Hughes D. W. Asteroidal size distribution / D. W. Hughes // Mon. Not. R. Astron. Soc., 1982. - V. 199. - P. 1149-1157.

4. Masiero Joseph R., Mainzer A. K., Grav T. et. al. Main Belt Asteroids with WISE/NEOWISE. I. Preliminary albedos and diameters / Masiero R. Joseph, A. K. Mainzer, T. Grav // Astrophys Journal. - 2011. - 741. - 2. - P. 20

5. Tedesco Edward F., Noah Paul V., Noah Meg, Price Stephan D. The supplemental IRAS minor planet survey / F. Tedesco Edward, V. Noah Paul, Noah Meg, D. Price Stephan // The Astronomical Journal. - 2002. - 123. - P. 1056-1085.

6. Rabinowitz D. L., Bowell E., Shoemaker E., Muinonen K. The population of Earth-crossing asteroids / D. L. Rabinowitz, E. Bowell, E. Shoemaker, K. Muinonen // In: Gehrels T. (ed.) HAZARDS DUE TO COMETS \& ASTEROIDS. Univ. of Arizona Press., 1994. - P. 285-312.

Надійшла до редколегії 25.09.17

А. Казанцев, канд. физ.-мат. наук,

Л. Казанцева, канд. физ.-мат. наук, Астрономическая лаборатория

Киевского национального университета имени Тараса Шевченко

\section{РАСПРЕДЕЛЕНИЕ ПО РАЗМЕРАМ АСТЕРОИДОВ ГЛАВНОГО ПОЯСА И ОТДЕЛЬНЫХ СЕМЕЙСТВ}

Построено распределение по размерам астероидов семейства Еос. При этом использовано базу WISE, которая содержит альбедо p и размеры $D$ более 80 тысяч астероидов. Показатель степени b степенной завесимости распределения имеет минимум при некотрых средних значениях размеров астероидов семейства. Подобная зависимость $b(D)$ имеет место и для всего пояса астероидов. Cделано предположение про возможное сходство механизмов формирования всего пояса астероидов и отдельных семейств.

Ключевые слова: астероиды, семейства астероидов.

Kazantzev A., Ph.D., Kazantzeva L., Ph.D. Taras Shevchenko National University of Kiev

\section{ASTEROID SIZE DISTRIBUTIONS FOR THE MAIN BELT AND FOR ASTEROID FAMILIES}

The asteroid-size distribution for he Eos family was constructed. The WISE database containing the albedo $p$ and the size $D$ of over 80,000 asteroids was used. The $b$ parameter of the power-law dependence has a minimum at some average values of the asteroid size of the family. A similar dependence $b(D)$ exists for the whole asteroid belt. An assumption on the possible similarity of the formation mechanisms of the asteroid belt as a whole and separate families is made.

Keywords: asteroids, asteroid families.

Удк 520.86

В. Карбовський, інженер, Головна астрономічна обсерваторія НАН України, В. Клещонок, канд. фріз.-мат. наук,

М. Буромський, інженер,

Київський національний університет імені Тараса Шевченка

\section{ПРОГРАМНИЙ ТА АПАРАТНИЙ КОМПЛЕКС ДЛЯ СПОСТЕРЕЖЕННЯ ПОКРИТТЯ ЗІР АСТЕРОЇДАМИ}

2016 р. розпочато підготовку до програми спостереження покриття зір астероїдами на телескопі АЗТ-2. Запропоновано і розроблено новий метод реєстрації покриття за допомогою ПЗ3-камери в режимі синхронного переносу. Написано спеціальна програма для керування ПЗ3 камерою й запису зображень під час таких спостережень. Швидкість перенесення зображення може змінюватися в широких межах, що дає можливість проводити спостереження в широкому діапазоні зоряних величин. Використовується телескоп АЗТ-2, який має найбільший діаметр дзеркала в Києві ( $D=0.7$ м. F = 10.5 м.). Розроблено та виготовлено трикратний оптичний редуктор, що забезпечує поле зору з Пз3камерою Apogee Alta U47 10 кутових мінут і еквівалентну фокусну відстань телескопа 3.2 м. Наведено результати тестових спостережень. Програма виконується спільно з Головною астрономічною обсерваторією НАН України та Астрономічною обсерваторією Київського національного університету імені Тараса Шевченка.

Ключові слова: астероїди, покриття зір, швидка фотометрія. 